\title{
OMENAPUUN JUURISTOSTA
}

\author{
JOUKO VUORINEN \\ Maatalouden tutkimuskeskus, Maantutkimuslaitos
}

Saapunut 3. 2. 1958

Hedelmätarhan maaperän viljavuuden tutkimiseen on pyritty löytämään sopivia menetelmiä. Käsillä oleva tutkimus, joka liittyy laajempaan Suomessa ja keski-Euroopassa vuosina 1955-1957 suoritettuun maaperätutkimukseeni, koettaa osaltaan selvittää mihin maakerroksiin on huomio kiinnitettävä hedelmätarhojen viljavuustutkimuksessa. Samoin kuin peltoviljelyn perustus on kasviston juurten leviämisen tunteminen.(11) samoin hedelmätarhassa on tunnettava nämä seikat tarkoituksenmukaisen viljelyn perustana. Toisaalta eri kasvilajeilla on juuriston sijoittumisessa todettavissa vastaavaa omintakeista muotoa kuin niillä on oma maanpäällinen tyypillinen muotonsa (5). Viljelymahdollisuudet ja viljelytoimenpiteet ovat tietysti suuresti riippuvaisia nimenomaan juuriston sijoittumisesta.

Tämän tutkimuksen kenttätyö on suoritettu neljässä hedelmätarhassa, nimittäin Kangasalan Pikkolassa hiekka- ja hiesumaalla, Pälkäneen Myttälässä hietamaalla, Hirvensalon Koivulassa aitosavella ja Puolan hedelmäviljelytieteen laitoksella Skierniewicessä. Koekaivauksia suoritettiin lisäksi muissa Puolan hedelmätarhoissa samoinkuin Länsi-Saksassa ja Tanskassa.

Tässä työssä käsitellään omenapuiden juuristokysymystä; tutkimuksen maaperäpuoli käsitellään ja julkaistaan erikseen.

\section{Tutkimusmenetelmä}

Puutarhassa ei ole sellaisia vaikeuksia kuin metsäpuiden juuristotutkimuksessa $(9,16)$, mutta puiden laajalle levinneen juuriston tutkiminen on kuitenkin melko hankalaa kun juurien hienoimmat osat ovat vaikeasti irroitettavissa varsinkin jäykistä maalajeista. Irroittamiseen on käytetty vettä (3), jolloin suuren laikatun maasärmiön sisältämä juuristo on ennakolta tietyllä verkko- ja puikkolaitteella sidottu. Tällaista liettämistä on käytetty (13) myös meillä peltokasvien juuristotutkimuksissa. Vastaavanlainen pienten juuristojen tutkimusmenetelmä on pienen maapilarin katkominen tiettyihin pätkiin ja niiden juottaminen paraffiinilla taas toisiinsa (1). Tällöin sitoutuvat katkenneet juurten päät paraffiinilevyihin, jotka taas on sidottu liettämislaitteeseen. 
Puiden juuriston tutkimuksessa on turvauduttava suuritöiseen kaivamiseen. WEAVER (14) ja LAITAKARI (9) ovat kaivaneet kuiviltaan (ilman vesikäsittelyjä) suuren määrän juuristoja ja tarkoin kuvanneet juurten kulun seuraamalla kutakin tutkittavaa juurta latvoille saakka. Päinvastainen menetelmä on katkaista juuristo tietyiltä etäisyyksiltä (6) ja selvittää tällaisen maaleikkauspinnan läpäisevät juuret.

Juuriston tehoa ajatellen on kiinnitetty huomiota erityisesti juurten pintaalaan $(12,2,7)$. Toisaalta on nimenomaan hienojen juurten jakautumista pidetty silmällä kun puista on tutkittu juurten pituus (4).

Tämän tutkimuksen järjestelyssä on käytetty tietyn maatilavuuden (8) juurten erottamista kuiviltaan (14) ja juurten jakamista kahteen fraktioon yli ja alle

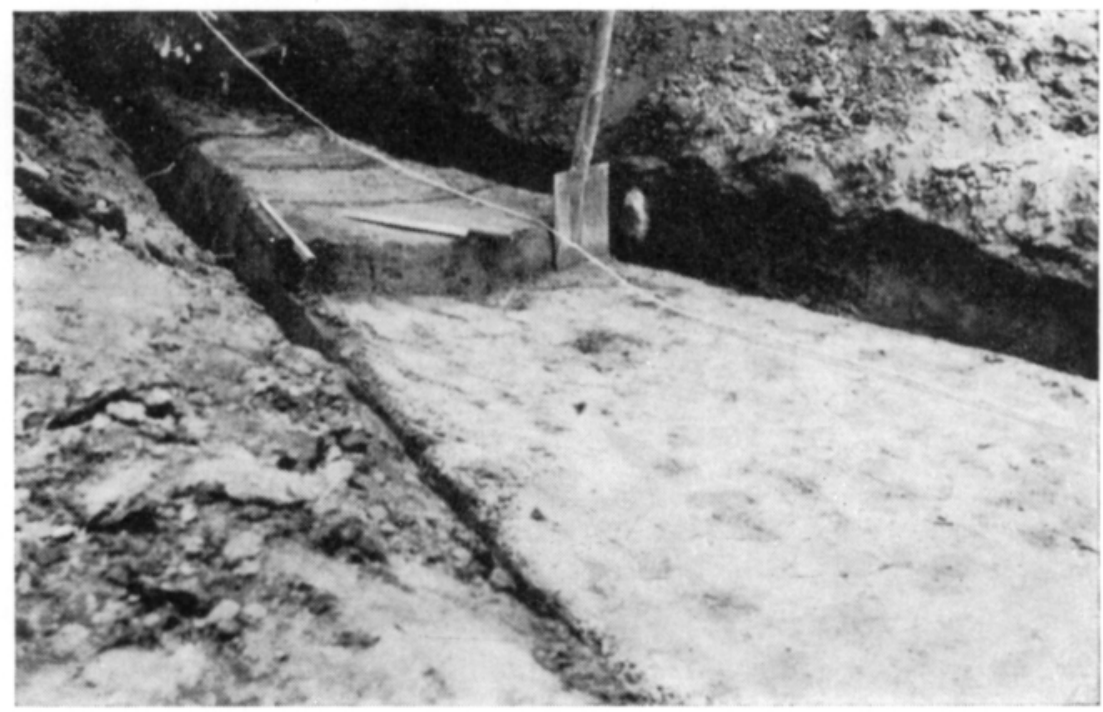

Kuva 1 - Picture 1

$2 \mathrm{~mm}$ (vert. 7). Tulosten esittämisessä taas on koetettu saada selväksi nimenomaan juurten jakautuminen maassa (4).

Tässä tutkimuksessa on menetelty niin, että puun rungosta lähtien on otettu $30-180^{\circ}$ :n sektori työn alle. Tutkiminen aloitettiin sektorin kehältä niin kaukana puun rungosta, että juuria ei enää koepistoissa tavattu, taikka oltiin jo tutkittavan ja naapuripuun puolivälissä. Työn suoritusta varten sektori (isoilla puilla $30^{\circ}$, pienillä $60-180^{\circ}$ ) jaettiin $30 \mathrm{~cm}$ leveisiin kaistaleisiin niin, että puun runko keskipisteenä piirrettiin kaaret säteen jokaisen $30 \mathrm{~cm}: n$ päähän. Näin saaduista kaistaleista kaivettiin koko maa kerroksittain tutkittavaksi. Multakerroksen kohdalla nämä tutkimuskerrokset olivat $5 \mathrm{~cm}$ ja syvemmällä $10 \mathrm{~cm}$ tai aivan pohjassa $20 \mathrm{~cm}$ paksuja. Parhaaksi työjärjestykseksi osoittautui maan pinnan myötäinen kaivaminen. Näin leikattiin siis kaistale kaistaleelta kerros $0-5 \mathrm{~cm}$. Kunkin kaistaleen maa luotiin seulalle, jossa se käsin hienonnettiin ja eroteltiin juuret maasta. Ne puhdisteltiin kevyesti hieromalla ja maa ravisteltiin pois ennen punnitusta. Juuret 
lajiteltiin samalla paksuihin $(>2 \mathrm{~mm})$ ja hienoihin $(<2 \mathrm{~mm})$. Kun yksi kerros oli kokonaan poistettu, piirrettiin tasaiselle sektorin pinnalle tutkittavat kaistaleet uudelleen (kuva 1). Kunkin tutkitun maatilavuuden sisältämät juurierät on käsittelyä varten ilmaistu grammoina 100 maalitraa kohti.

\section{Tutkimuksen tuloksia}

Seuraavassa esitän ensin kunkin tutkitun tapauksen ja myöhemmin tarkastelen erilaisten tekijöiden vaikutusta.

1. Normandie-taimisto, Pikkola, Kangasala (N:o 15431/16 —, 15482/10—, 15517/1-). Maalaji on hieno hiekka ja taimisto siemenestä saakka paikallaan 5 vuotta kasvanutta perusrunkoa (15).

Tutkimus suoritettiin metrin levyisenä kaistaleena poikki neljärivisen taimiston. Eri riveissä tuli tutkittavalle alueelle seuraavat määrät taimia, joiden keskimääräinen paksuus on myös ilmoitettu:

\begin{tabular}{|c|c|c|c|}
\hline Rivi & Maaleikkauksen n:o & Taimia kpl & Keskim. rungon paksuus \\
\hline Line & $\begin{array}{c}\text { Soil profile } \\
\mathrm{No}\end{array}$ & Number of plants & Average thickness of the stocks \\
\hline
\end{tabular}

\begin{tabular}{llrl}
\hline 1 & 3 & 10 & $13.2 \mathrm{~mm}$ \\
2 & 5 & 13 & 10.6, \\
3 & 7 & 9 & 11.7, \\
4 & 9 & 10 & 14.5,
\end{tabular}

Rungon paksuusluvuissa näkyy selvästi lohkon reunavaikutusta.

Juuriston sijainti ja tiheys näiden taimirivien alla on esitetty (piirros 1) poikkileikkauksena. Juuritiheyden kuvaamiseen on käytetty seuraavaa asteikkoa:

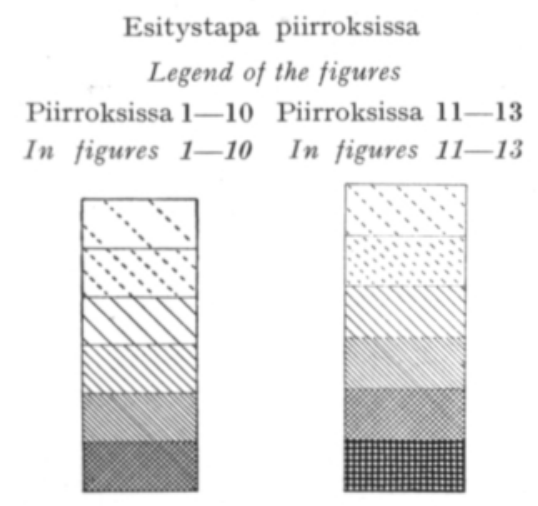

$$
\begin{gathered}
\text { Paksuja juuria } \\
\text { Coarse roots } \\
\mathrm{g} / 1001 \\
0 \\
1-100 \\
100-200 \\
200-400 \\
400-800 \\
800-1600 \\
>1600
\end{gathered}
$$

Hienoja juuria
Fine roots
$\mathrm{g} / 1001$
0
$1-10$
$10-20$
$20-40$
$40-80$
$80-160$
$>160$

Juuriston suurin syvyys eri riveissä vaihtelee $60-120 \mathrm{~cm}$, mutta tiheämpi juuriverkosto rajoittuu yleensä matalampaan kerrokseen. Paksujen juurten pääosa on vain taimien kohdalla (puolen metrin kaistaleella) ja ulottuu n. $20 \mathrm{~cm}$ :n syvyyteen. Hienompi juuristo ulottuu melko tiheänä n. $60 \mathrm{~cm}$ :iin, mutta senkin pääosa rajoittuu multakerrokseen $(0-20 \mathrm{~cm})$ ja täyttää maan myös taimirivien välillä. Erityisen tiheä on hieno juuristo multakerroksen alaosassa $(15-20 \mathrm{~cm})$. 
Paksuja juuria-Coarse roots

(N: $15431 / 16-$

$15482 / 10-$

Normandie-perusrunkotaimisto. Pikkola,Kangasala,HHk, 1956

$15517 / 1-)$

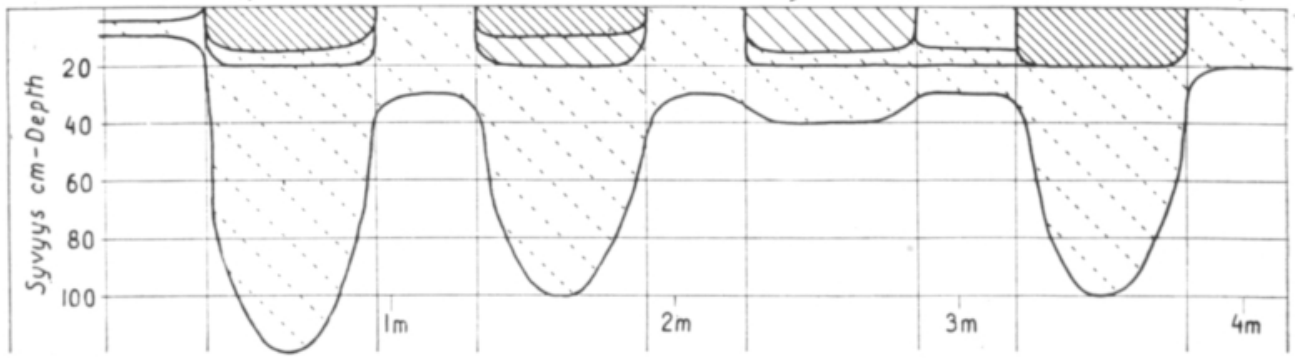

Hienojo juurio-Fine roors ${ }^{3}$

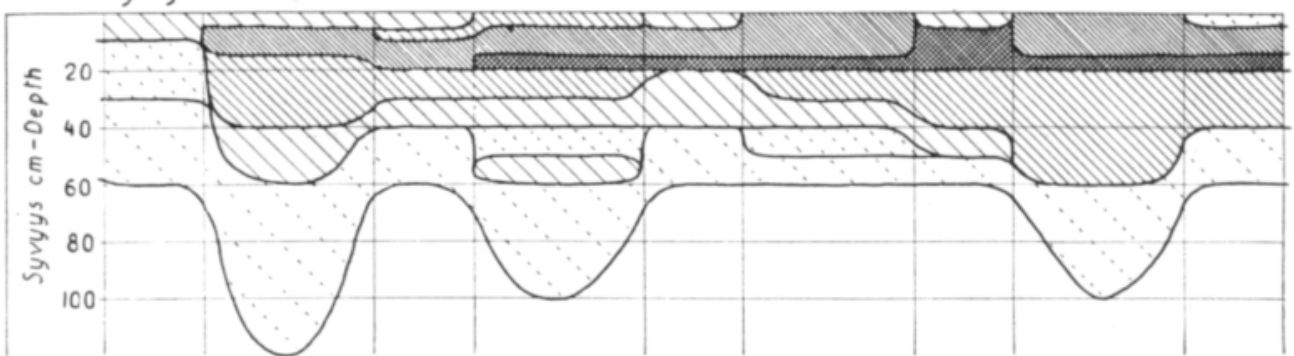

Piirr. 1 - Fig. 1

2. Lobo, yksinäinen taimistopuu, Pikkola, Kangasala (N:o 15431/10-11). Maalaji on hieno hiekka ja puun ikä taimistossa jalostuksen jälkeen 5 vuotta. Varttaminen suoritettiin käsityönä ja perusrungon juuret katkaistiin n. $15 \mathrm{sm}: \mathrm{n}$ mittaisiksi ennen istutusta. Puu oli jäännöskappale ja ollut yksinäisenä kaksi vuotta. Juuret tutkittiin $180^{\circ}$ :n sektorista.

Juuristo leviää yli metrin säteellä (piirros 2) ja $40 \mathrm{~cm}: n$ syvyyteen, mutta pääosa sekä paksuista, että hienoista juurista rajoittuu $90 \mathrm{~cm}: n$ säteiselle ympyrälle ja vain $0-20 \mathrm{~cm}$ :n syvyydelle. Juuriston halkaisija oli n. $2.4 \mathrm{~m}$ ja latvuksen n. puolet siitä.

3. Melba, Pikkola, Kangasala (N:o 15431/7 -9). Puu on 5 vuotta kasvanut paikallaan karkeahkossa hienossa hiekassa $(0-60 \mathrm{~cm})$. Tutkimus suoritettiin $60^{\circ}:$ n sektorissa.
Paksuja juuria-
Coarse roots
Hienoja juuria-
Fine roots

Kangasala, yksinäinen raimistopuu, Lobo (N: 15431/10-11)
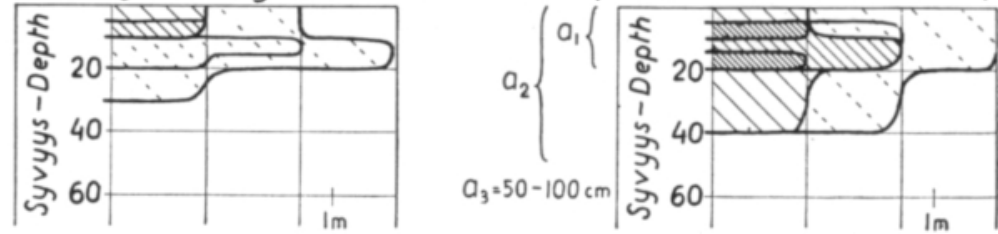
I
2
3
4

Piirr. 2 - Fig. 2 
Paksujo juuria -

Coorse roots

Kangasala, Pikkola, Melba, 1956

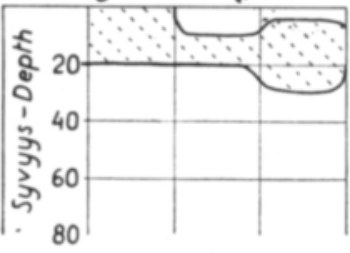

Hienoja juuria-

Fine roots

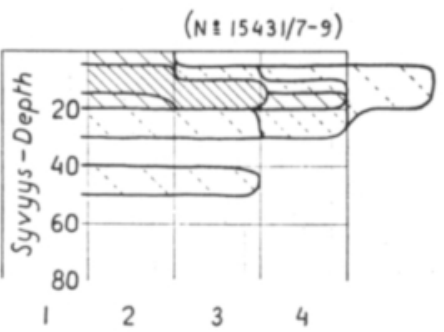

Piirr. 3 - Fig. 3

Paksut juuret ulottuvat yli metrin etäisyydelle, mutta vain $30 \mathrm{~cm}$ syvään. Hienojen juurten alueen ulkokehä on 1.5 metriä puun rungosta ja niitä on tavattu vielä $50 \mathrm{~cm}: n$ syvyydessä. Pääosa hienoista juurista on tässäkin sijoittunut multakerrokseen (piirros 3). Tässä juuristossa on näkyvissä myös pintamaan $(0-5 \mathrm{~cm})$ tyhjyys $60 \mathrm{~cm}$ ulompana rungosta.

4. Melba, Pikkola, Kangasala (N:o 15424/1-6). Karkeahko hieno hiekka, puun ikä 10 vuotta. Tutkimus on suoritettu $30^{\circ}$ :n sektorissa, joka suunnattiin vinosti puiden riviväliin.

Paksu juuristo ulottuu n. $2.4 \mathrm{~m}: n$ päähän rungosta ja sijaitsee multakerroksessa. Vain rungon lähellä $(60-90 \mathrm{~cm})$ jotkut haarat työntyvät syvemmälle $(50 \mathrm{~cm})$. Aivan samanlainen jakautuminen näkyy tämän puun hienoissa juurissa. Pieni

Paksuja juuria-Coarse roots

( $\cong 15424 / I-6)$

Kangasala, Pikkola, Melba, 1956

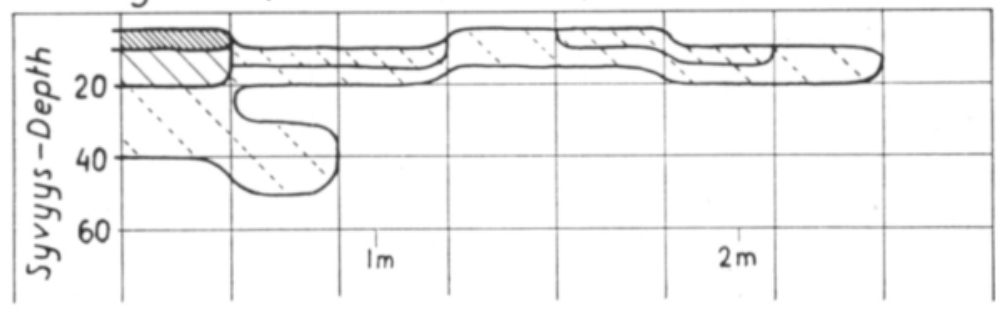

$\begin{array}{lllllllll}1 & 2 & 3 & 4 & 5 & 6 & 7 & 8 & 9\end{array}$

Hienoja juuria-Fine roots

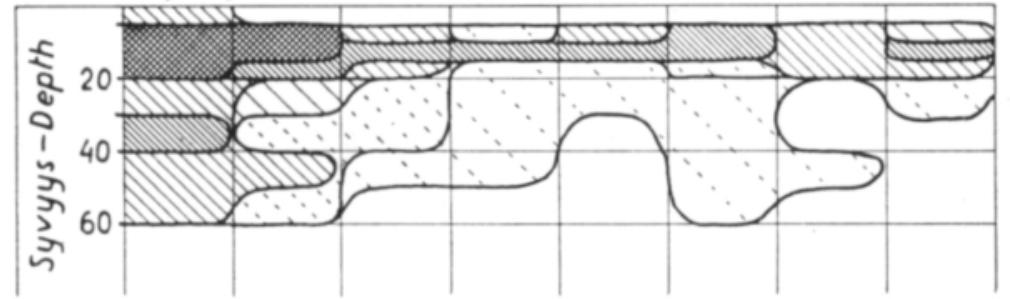

Piirr. 4 - Fig. 4 


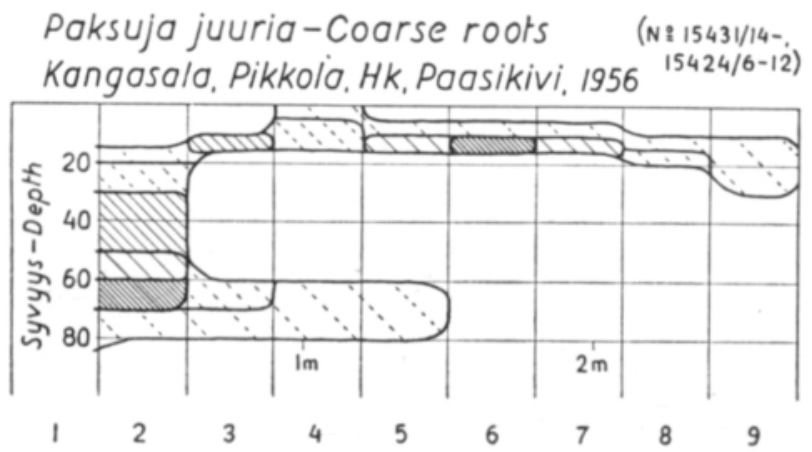

Hienoja juuria-Fine roots

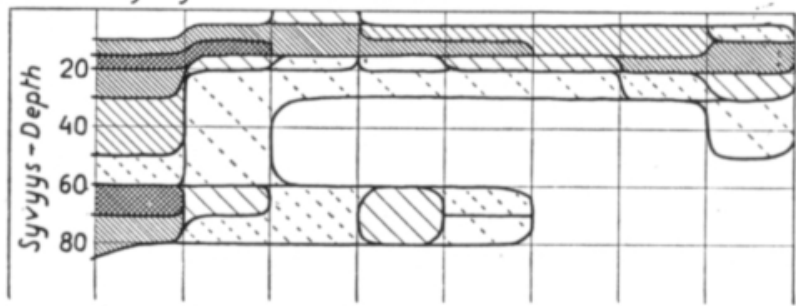

Piirr. 5 - Fig. 5

juuritihentymä 2.4-2.7 m:n päässä rungosta viittaa jo naapuripuun juuriston läheisyyteen. Valtaosa hienoa juuristoa on tälläkin puulla multakerroksessa, jossa sen tiheys on hyvin suuri $90 \mathrm{~cm}$ :iin saakka rungosta. Multakerroksen ylin osa $(0-5$ $\mathrm{cm}$ ) on kokonaan tyhjä juurista (piirros 4).

5. Paasikivi, Pikkola, Kangasala (N:o 15431/14-, 15424/6-12). Maalaji $0-60 \mathrm{~cm}$ karkeahko hieno hiekka, 60-100 hieta. Puu oli 11 vuotias ja lähellä edellä kuvattua Melbaa. Tutkittu sektori $30^{\circ}$.

Juuristokuva (piirros 5) on hyvin samanlainen kuin edellä Melbassa. Hiekassa juuristo on levittäytynyt pääasiassa multakerrokseen. Alempi juuristotaso on kehittynyt hietamaahan, joka on huomattavan kostea huolimatta siitä, että pohjavesi on noin 8 metrin syvyydessä.

6 ja 7. Kaksi Kaneliomenapuuta, Myttäälä, Pälkäne. Näistä toinen (N:o 15299) kasvaa mullosmaassa ja toisen (N:o 15301) alusta on ollut neljä vuotta nurmikompostina. Nurmi on koiranheinää, josta niitetty ruoho on koottu puiden alle. Lisäksi on kompostissa käytetty olkea. Kompostikatteen leveys puurivin alla oli $4.8 \mathrm{~m}$. Maalaji on hienoa hietaa. Puut olivat 21 vuotta vanhoja. Rungon halkaisija $1 / 2 \mathrm{~m}$ korkeudessa $18 \mathrm{~cm}$ ja latvuksen halkaisija $\mathrm{n} .8 \mathrm{~m}$ sekä puiden korkeus $\mathrm{n}$. $5 \mathrm{~m}$. Tutkittu sektori oli $30^{\circ}$ ja suunnattuna suoraan puurivistä ulos (lounaaseen).

Juuristot on esitetty piirroksissa 6 ja 7 siten, että paksut ju u ret on esitetty piirroksessa 6 mullosmaassa ja nurmikompostimaassa kasvaneista puista. Samoin on esitetty (piirros 7) hienot juuret. Juuristo ulottuu viereisen rivin puiden juuriin ja yleensä yhden metrin syvyyteen. Vain rungon lähellä (n. $90 \mathrm{~cm}: n$ säteellä) tavattiin vielä syvemmälle meneviä juuria kummallakin puulla. 
Paksuja juuria-Coarse roots

Myträälä, Pälkäne. HHt. 1955

(N: 15299)

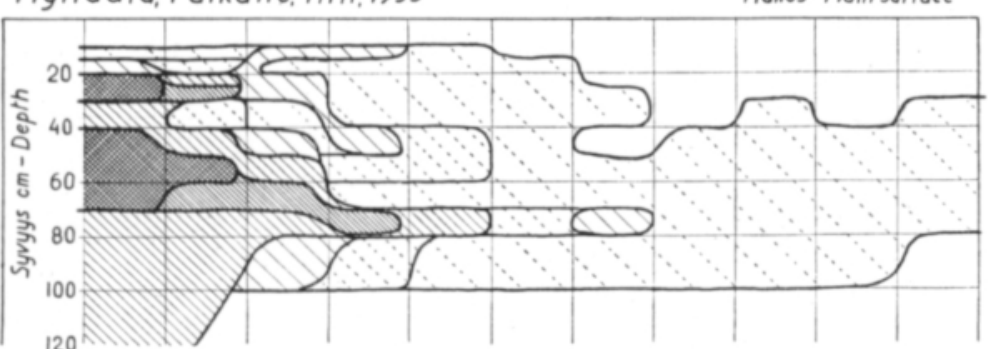

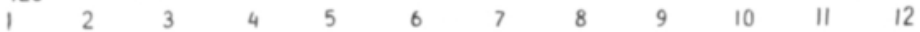

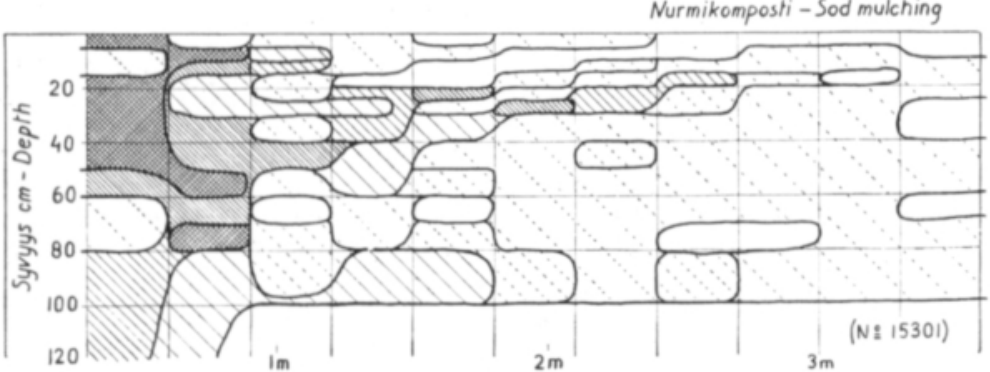

Piirr. 6 - Fig. 6

Mullosmaassa (N:o 15299) on koko pintakerros $(0-10 \mathrm{~cm})$ juuretonta, mutta yli 2 metrin etäisyydellä rungosta ulottuu tyhjä kerros $30-40 \mathrm{~cm}: n$ syvyyteen. Tällä kohtaa on puurivien välinen traktorilla ajettu kaistale. Paksujen juurten

Hienoja juurio-Fine roots

Myträalä, Pälkäne. HHt. 1955

(N: 15299)
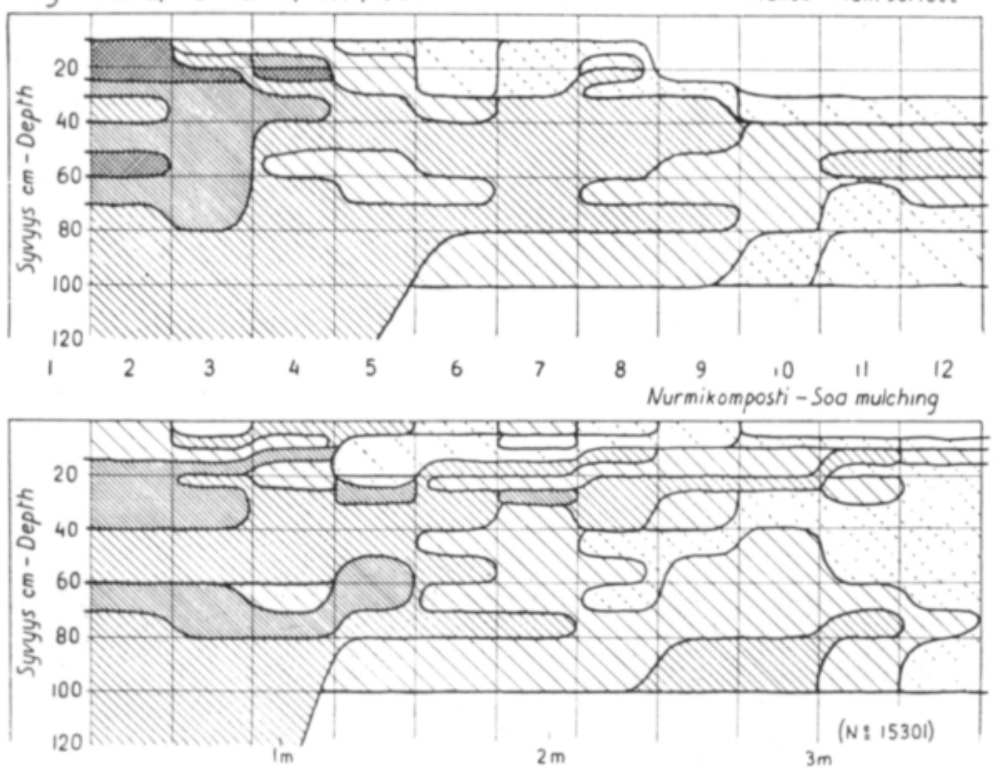

Piirr. 7 - Fig. 7 
tihentymä näyttää myös suuntautuvan alaspäin ja ulottuu $70-80 \mathrm{~cm}$ :n syvyydessä yli kahden metrin päähän rungosta.

Nurmikompostin (N:o 15301) alla on juuristokuva huomattavasti toisenlainen. Paksutkin juuret ulottuvat pintaan saakka ja vain 5 tai $10 \mathrm{~cm}$ on juurettomana traktoriajokaistan kohdalla. Juuritihentymissä todetaan voimakasta vinosti ylöspäin suuntautuvaa keskittymistä. Näistä eräs lähtee n. 1.5 metrin päässä $40 \mathrm{~cm}: \mathrm{n}$ syvyydestä ja ulottuu 3 metrin päähän rungosta $15-20 \mathrm{~cm}$ :iin pinnasta.

H i e n o je n j u u r en (piirros 7) antama yleiskuva on samanlainen kuin paksujen. Mullosmaassa ei niitä ole pintakerroksessa $(0-10 \mathrm{~cm})$ eikä traktoriväylällä $(0-30 \mathrm{~cm})$. Nurmikompostin alla sensijaan vain $0-5 \mathrm{~cm}$ ajoväylän kohdalla on juuretonta ja juuritihentymien suuntautuminen ylöspäin on aivan vastaavanlainen kuin paksuillakin juurilla. Mullosmaan (N:o 15299) sektoriin tuli jo uloimpiin kaistaleisiin vastassa olevan naapuripuun juuria niinkuin piirroksestakin näkyy (50-70 cm syvällä).

8. Wealthy, Pikkola, Kangasala (N:o 15649/9-13). Maalaji hiesu, multakerros hietainen ja multava. Puun ikä 4 vuotta, latvuksen halkaisija $1.2 \mathrm{~m}$ ja puun korkeus $2.2 \mathrm{~m}$ sekä rungon halkaisia $1 / 2$ metrin korkeudessa $36 \mathrm{~mm}$. Tutkittu sektori $60^{\circ}$.

Puu kasvaa mullosmaalla, joten sen juuristo ei ulotu pintaan (piirros 8). Paksut juuret ulottuvat 1.5 metrin ja hienot 2 metrin päähän rungosta. Juuristo ulottuu $40-50 \mathrm{~cm}$ maanpinnasta ja tihentymät työntyvät vaakasuoraan multakerroksen alaosassa $(15-20 \mathrm{~cm})$.

9. Toinen tiiviin maan tutkimuskohde oli Wealthy, Koivula, Hirvensalo (N:o 15438). Maalaji on hyvin jäykkä aitosavi ja puun ikä noin 18 vuotta. Tutkittu sektori oli $30^{\circ}$.

Juuristo on hyvin matala (piirros 9). Vain muutamassa kohdassa se ulottuu $90 \mathrm{~cm}: n$ syvyyteen. Se muodostaa melko tasatiheän juurikerroksen $(10-70 \mathrm{~cm})$, joka ulottuu yli 3.6 metriä rungosta. Maa on pidetty mulloksella, joten puolet

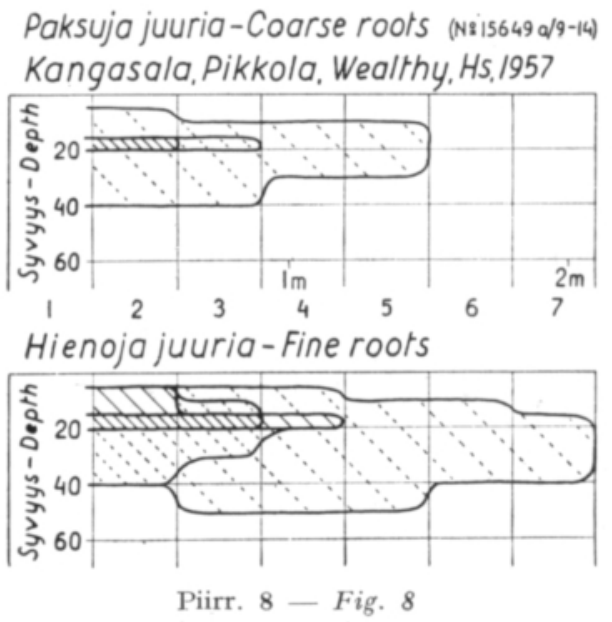


Paksuja juuria - Coarse roots

Koivula, Hirvensalo, As, Wealthy, 1956

(N: 15438)

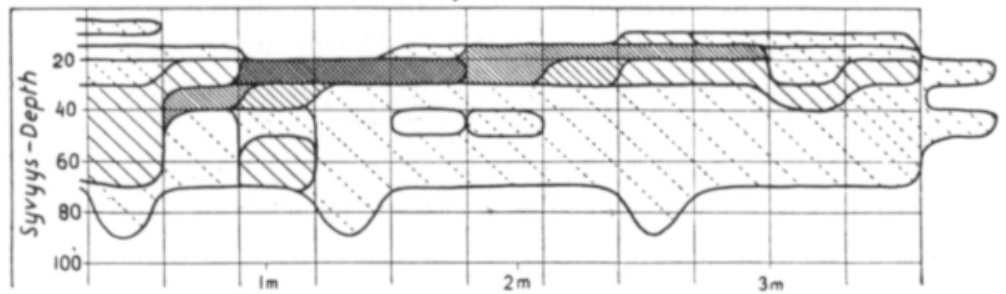

Hienoja juuria - Fine roots

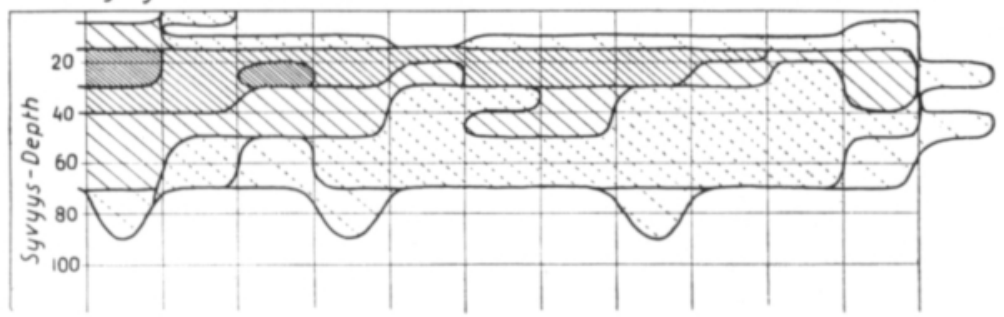

Jiirr. 9 - Fig. 9

multakerroksesta on juuretonta. Vain lähellä runkoa nousevat hienot juuret pintaan puun juurella olleen katteen turvin. Juuritihentymä on hyvin tiivistä ja keskittynyt melko tasaisesti $15-30 \mathrm{~cm}$ :n kerrokseen.

10. Skierniewice, Puola (N:o 15602). Maalaji $\mathrm{C}-50 \mathrm{~cm}$ hieta, $5 \mathrm{C}-100 \mathrm{~cm}$ hietainen savi, Gleymuodostumaa $30-80 \mathrm{~cm}$ ja mergeliä $80-100 \mathrm{~cm}$. Omenapuun rungon paksuus noin $20 \mathrm{~cm}$. Tutkittu sektori oli $30^{\circ}$ ja juuristo selvitettiin $50 \mathrm{~cm}: \mathrm{n}$ kaistalein $1-5 \mathrm{~m}$ puun rungosta.

Paksuja juuria-Coarse roots Skierniewice, Poland, 1957

(N: 15602)

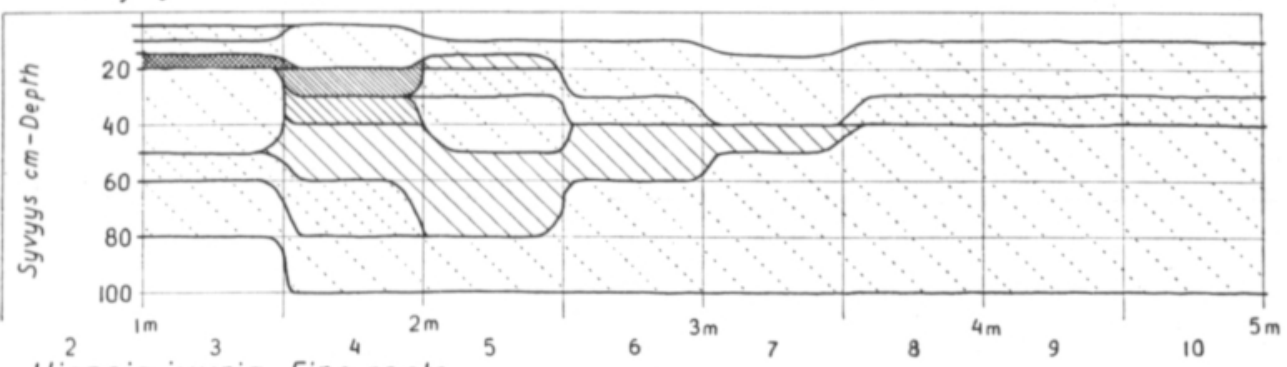

Hienoja juuria-Fine roots

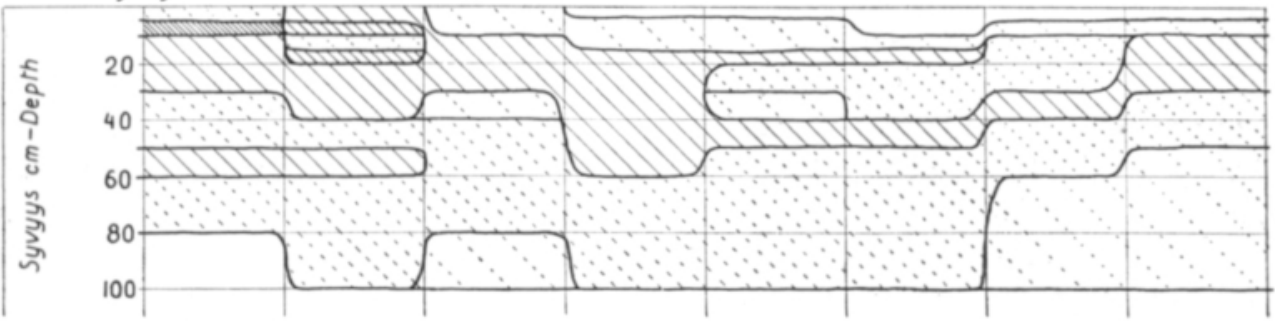

Piirr. 10 - Fig. 10 
Juuristo ulottuu melko tasaisesti metrin syvyyteen (piirros 10), mutta pintakerros on juuretonta. Tiheimmät paksujen juurten kansoittamat kerrokset ulottuvat 2.5 metrin ja 3.5 metrin päähän rungosta. Hienot juuret täyttävät suhteellisen tasaisesti koko maaleikkauksen aina 5 metrin päähän rungosta. Puun juurella kasvoi nurmi 2.5 metrin päähän rungosta, ja tällä alueella hienot juuret nousevat maan pintaan saakka. 2.5-5 metriin maa oli mulloksella ja vain 5 tai $10 \mathrm{~cm}$ oli juuretonta.

\section{Tulosten tarkastelua}

Tutkituista tapauksista on taulukossa 1 esitetty yleistiedot yhteenvetona. Puiden iän kasvaessa todetaan juuriston aluksi yleensä leviävän nopeammin kuin latvuksen. Nuorissa puissa juuriston halkaisija on ollut noin $1.5-3$ kertaa latvuksen halkaisija. Jo $4-5$ vuotiaassa tarhassa alkaa esim. $4 \times 4 \mathrm{~m}$ :n istutuksella koko maa olla juurten valtaamaa. Kymmenvuotiaalla puulla juuriston halkaisija on jo yli $5 \mathrm{~m}$ ja 20-vuotisella puulla oloissamme yli $7 \mathrm{~m}$. Puolassa suoritetussa tutkimuksessa todettiin vielä suurempaa vaakasuoraa juurten levenemistä.

Juuriston syvyys on vaihdellut eri ikäisillä puilla $0.4-1.0$ metriin. Aivan rungon alla olevaa juuristoa ei ole tutkittu muuta kuin taimistossa, jossa sen syvyys oli $1.2 \mathrm{~m}$. Vanhoissa puissa (Pälkäneellä) todettiin hiedassa myös tällaista syvempää juuristoa rungon lähellä. Muuten omenapuun juuristo on hyvin tasaisesti syvyyssuuntaan levinnyttä. Nuorilla puilla $(4-5 \mathrm{v})$ tämä syvyys on ollut $0.5 \mathrm{~m}$, ja lisääntyy syvyys iän mukana. Hiedassa juuristo on mennyt syvimmälle $(1 \mathrm{~m})$, mutta tiiviissä savessa jäänyt matalammaksi (n. $70-90 \mathrm{~cm}$ ).

Juuriston levinneisyydestä Suomen olosuhteissa on LEHTONEN (10) esittänyt hyvin vastaavanlaisia lukuja. Hänen mukaansa kuitenkaan juuriston halkaisija ei yleensä ollut niin suuri kuin tässä tutkimuksessa on todettu. LEHTONEN on esittänyt lukuja kahdeksasta puusta, joista olen laskenut seuraavat keskiarvot:

kpl

ikä latvuksen

juuriston

halkaisija syvyys

juuriston

halkaisija

$\begin{array}{lllll} & & \mathrm{m} & \mathrm{m} & \mathrm{m} \\ 3 & 5-9 & 2.5 & 2.7 & 0.5 \\ 5 & 12-16 & 4.0 & 4.9 & 0.8\end{array}$

Amerikassa on todettu (3) seitsenvuotiaan puun juuristo laajemmaksi kuin meillä (> $7 \mathrm{~m}: \mathrm{n}$ halkaisija) ja huomattavasti syvemmäksi (n. $2.7 \mathrm{~m}$ ). LeHTONEN (10) esittää myös aktiivisten hienojen juurten alueen melko suppeana vyöhykkeenä latvuksen ulkolaidan kohdalla. Tutkimuksessani ei tällaista vyöhykettä ole voitu osoittaa. Puun hienot juuret esiintyvät kyllä tietyllä tavalla tihentyminä. Pystysuorassa suunnassa tällainen tihentymä on usein multakerroksen alaosassa, mutta ulottuu melko tasaisena rungosta ulospäin. Näiden vyöhykkaiden tarkastelua varten ylhäältäpäin olen laatinut piirrosesityksiä muutamista tutkituista tapauksista. 


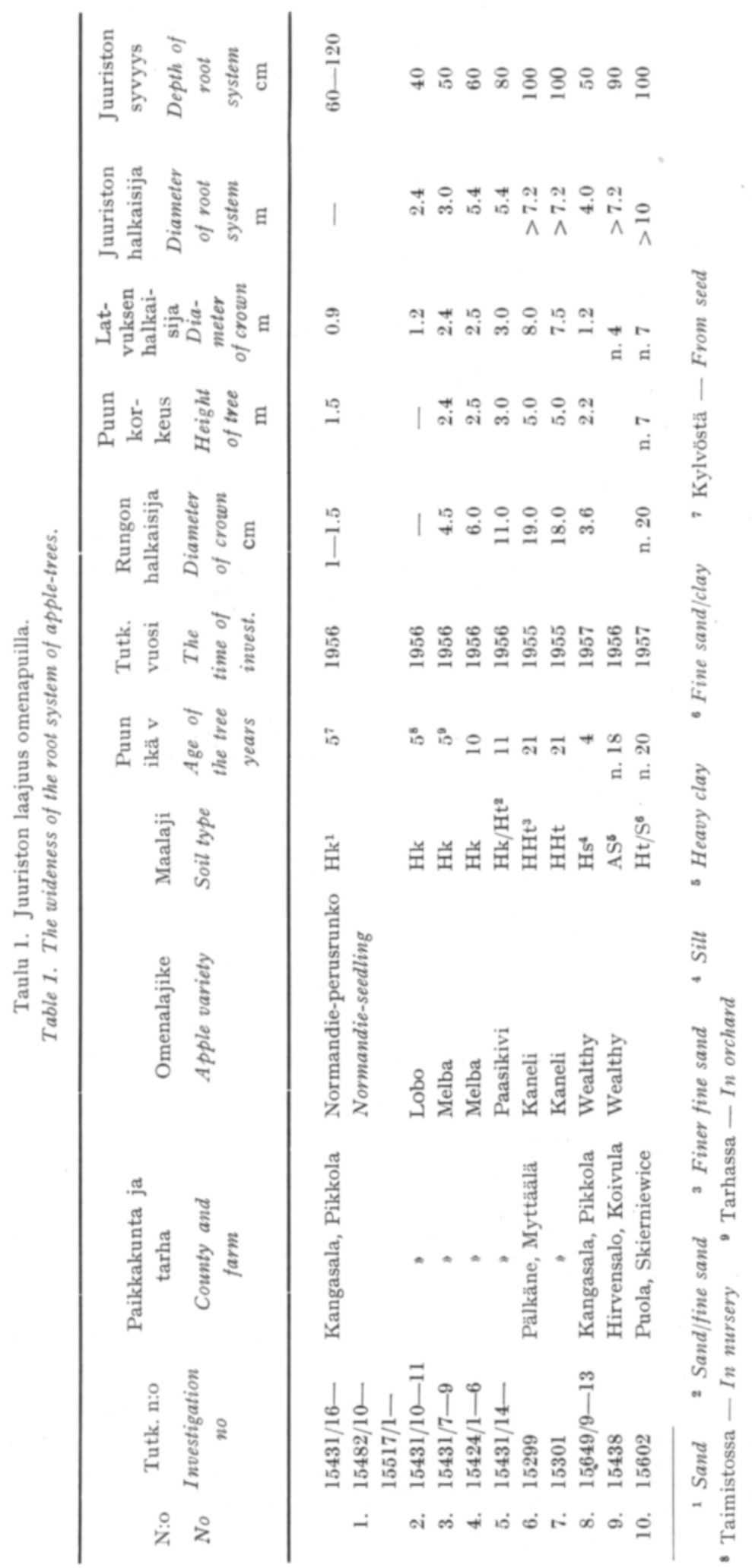




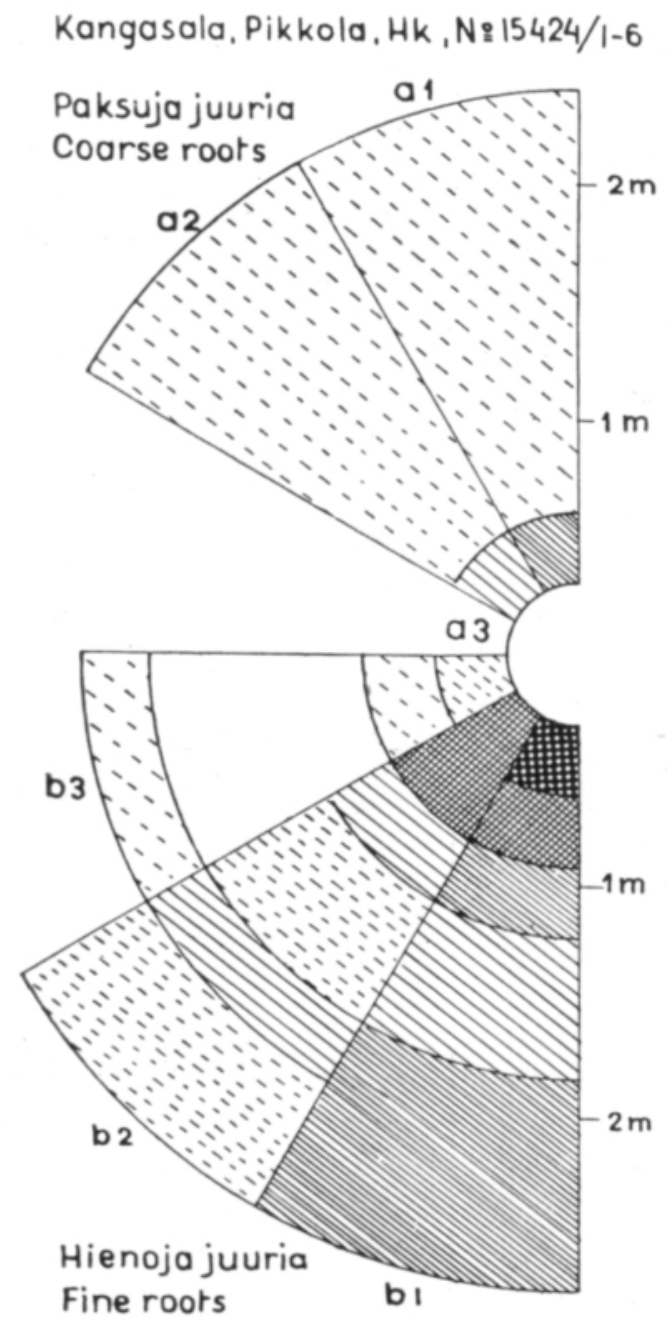

Piirr. 11 - Fig. 11

Piirroksessa 11 on esitetty Melban n:o 4 juuritiheydet (N:o 15424/1-6) hiekassa erikseen paksuista juurista (a) ja hienoista juurista (b). Eri sektorit puoliympyrällä tarkoittavat lisäksi juuritiheyksiä eri syvyisissä kerroksissa $(1=0-20$ $\mathrm{cm}, 2=0-50 \mathrm{~cm}$ ja $3=50-100 \mathrm{~cm}$ ). Piirroksesta todetaan, että paksuja juuria on tasaisesti, mutta hyvin vähän $0-20 \mathrm{~cm}$ :ssä $\left(a_{1}\right)$ ja samoin $0-50 \mathrm{~cm}: s s a ̈ ~\left(a_{2}\right)$. Syvemmällä $\left(a_{3}\right)$ ei näitä esiinnykään. Hyvin vähän on näin syvällä $(50-100 \mathrm{~cm})$ hienojakaan juuria $\left(b_{3}\right)$, mutta sensijaan runsaasti ylemmissä kerroksissa. Erityisesti on huomattava hienojen juurten tiheys multakerroksessa $(0-20 \mathrm{~cm})$. Tihein hieno juuristo on näin nuorella $(10 \mathrm{v})$ puulla alle metrin säteellä noin puolen metrin syvyyteen $\left(\mathrm{b}_{1} \mathrm{ja} \mathrm{b}_{2}\right)$. Kun latvus oli vain $2.5 \mathrm{~m}$ eli sen säde $1.25 \mathrm{~m}$ todetaan piirroksesta 11 että melko tiheä ja tasainen hieno juuristo ulottuu vielä 1.5 metriä latvuksen ulkopuolelle ja erityisen tiheänä multakerroksessa. 


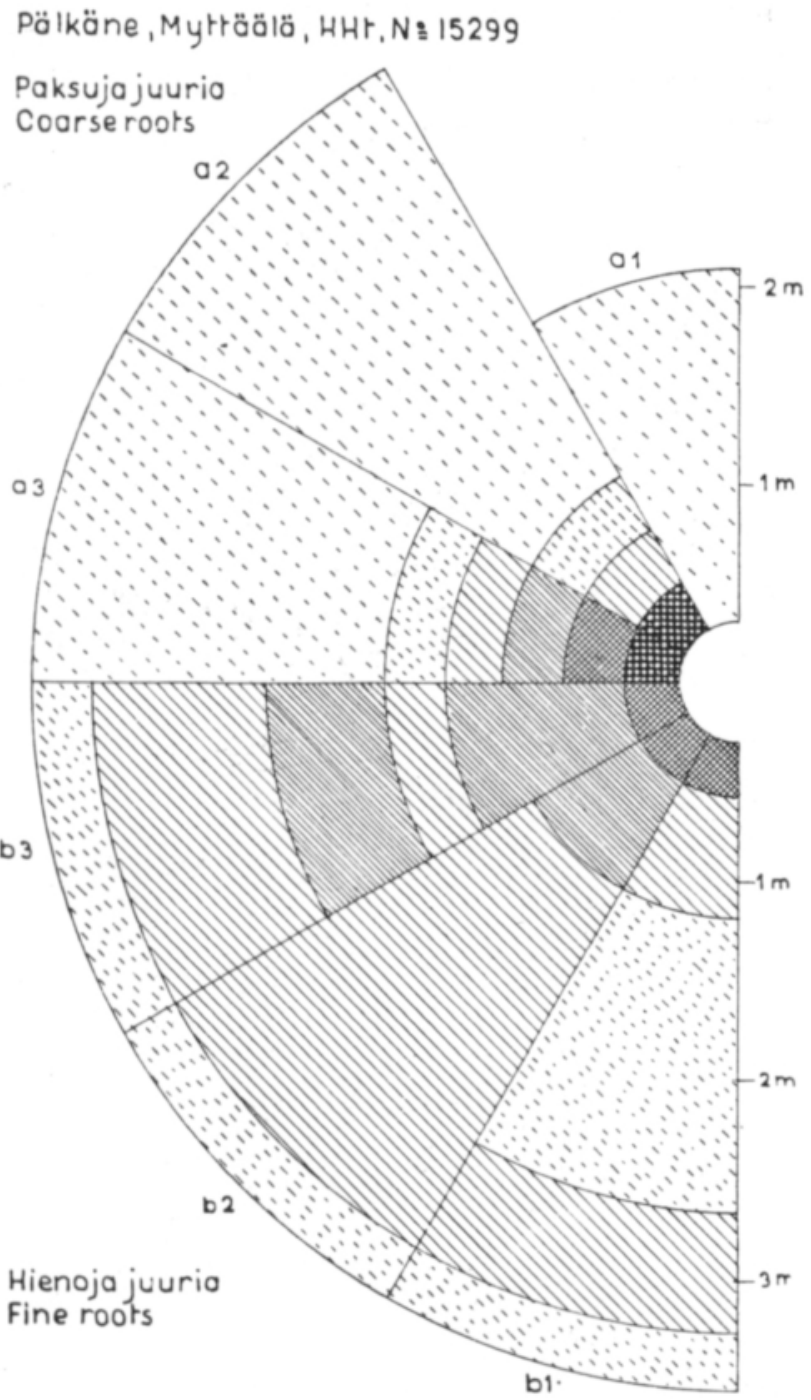

Piirr. $12-$ Fig. 12

Hiedassa (piirros 12) on juuriston sijoittuminen selvästi toisenlainen (N:o 15299) Kanelipuulla (n:o 6). Sen latvus peittää koko juuristoalueen (21 vuotias puu) ja juurten sijoittuminen syvempiin kerroksiin on ilmeinen. Erityisesti hienossa juurissa todetaan niiden suhteellisen runsas sijoittuminen multakerrosta syvemmälle (vertaa $\mathrm{b}_{2}: \mathrm{n}$ suhde $\mathrm{b}_{1}$ :een) ja nimenomaan pohjamaahan $50-100 \mathrm{~cm}\left(\mathrm{~b}_{3}\right)$.

Aitosavessa (piirros 13) todetaan myös Wealthyllä (n:o 9) juuriston voimakas keskittyminen $\left(\mathrm{a}_{2}\right.$ ja $\left.\mathrm{b}_{2}\right)$ multakerroksen alapuolelle $(20-50 \mathrm{~cm})$. Sensijaan puolta metriä syvemmällä on juuristotiheys jo hyvin pieni. Rungosta lähtien on tihein hieno juuristo $90 \mathrm{~cm}: n$ säteellä, mutta siitä ulospäin juuristo jatkuu melko tasaisen tiheänä ainakin $1.5 \mathrm{~m}$ latvuksen ulkopuolelle. 


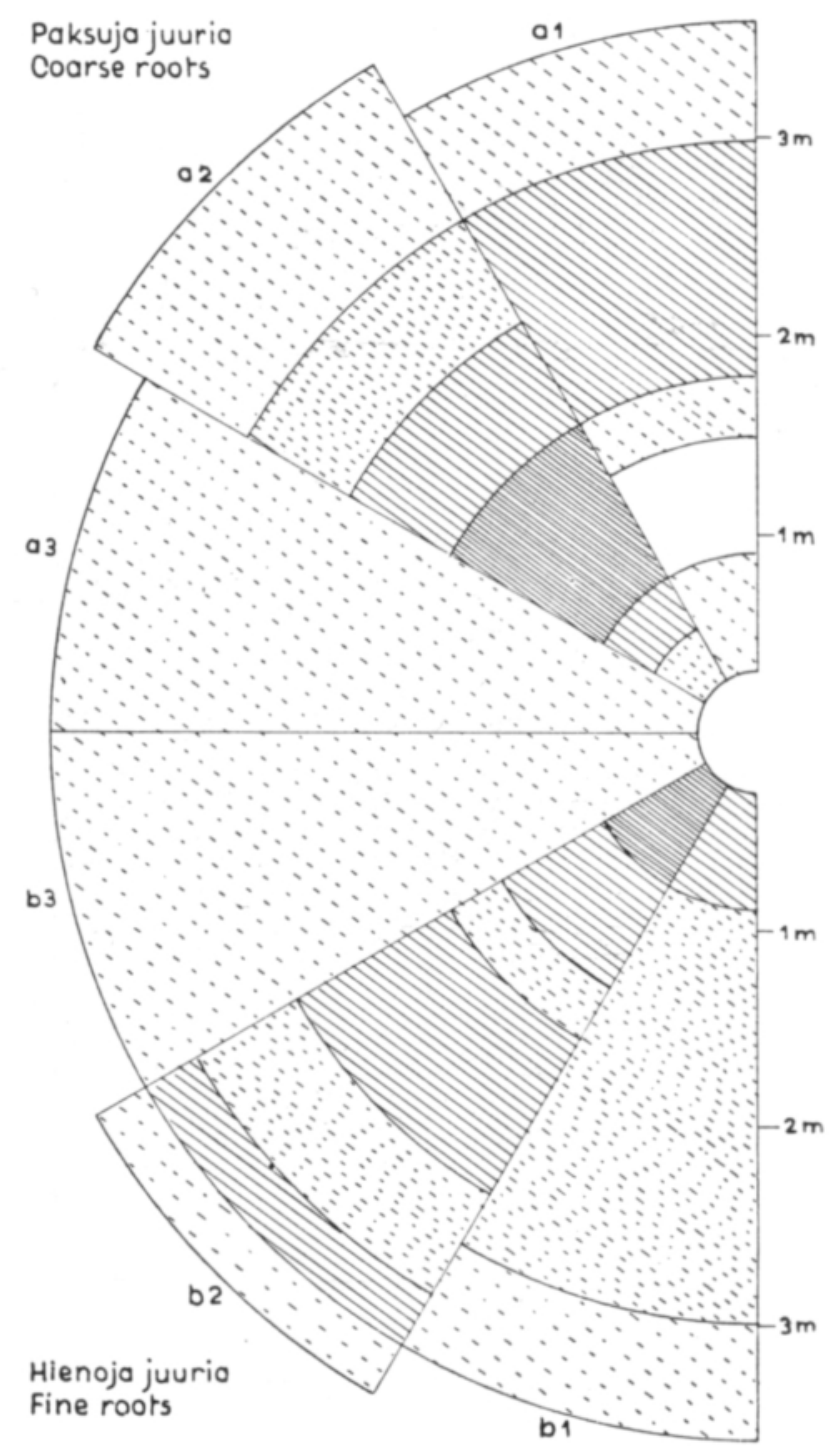

Piirr. 13 - Fig. 13

Juuriston laajuutta ei voida päätellä aina latvuksen perusteella, koska erityisesti puun hoito ja leikkaus vaikuttavat latvuksen samoin kuin toisaalta (3) uudestaan istutuksilla on vaikutuksensa juuriston muotoon ja laajuuteen. Sen vuoksi juuriston levinneisyyden tunteminen eri ikäisillä puilla ja eri maalajeissa on käytännössä tärkeätä.

Juurien syvyydestä tein vielä koekaivauksia Keski-Euroopan eri maissa. Näiden tulokset tukevat edellä esitettyjä käsityksiä nimenomaan juuriston syvyy- 
Taul. 2. Pääasiallinen juuriston syvyys eräiden ulkomailla suoritettujen tutkimusten mukaan.

Table 2. Main depth of root system of apple-trees in some countries.

\begin{tabular}{|c|c|c|c|c|}
\hline $\begin{array}{c}\text { Maa ja paikka- } \\
\text { kunta } \\
\text { Country and } \\
\text { county }\end{array}$ & $\begin{array}{r}\text { Multal } \\
\text { syv } \\
\text { Mould } \\
\text { laye }\end{array}$ & $\begin{array}{l}\text { kerroksen } \\
\text { yys } \mathrm{cm} \\
\text { containing } \\
r \mathrm{~cm} .\end{array}$ & $\begin{array}{l}\text { Puun ikä } \\
\text { vuosia } \\
\text { Age of the tree, } \\
\text { years }\end{array}$ & $\begin{array}{l}\text { Juuriston pääasi- } \\
\text { allinen syvyys cm } \\
\text { Main depth of the } \\
\text { root system } \mathrm{cm} .\end{array}$ \\
\hline $\begin{array}{l}\text { Puola, Belsk } \\
\text { - Poland }\end{array}$ & $\begin{array}{l}\text { Ht } 50 \mathrm{~cm} / \mathrm{HsS}+\text { mergeliä } \\
\text { Loam } 50 \mathrm{~cm} / \text { silt clay }+ \text { mergel }\end{array}$ & 45 & 12 & $20-50$ \\
\hline $\begin{array}{l}\text { Puola, Jozefow } \\
\text { - Poland }\end{array}$ & $\begin{array}{l}\text { hkSr } 30 \mathrm{~cm} \text { renzina, } \\
\text { särkynyt liitukallio } \\
\text { Cravel } 30 \mathrm{~cm} \text { renzin, lime rock }\end{array}$ & 20 & & $30-70$ \\
\hline $\begin{array}{l}\text { Puola, Lipowa } \\
\text { - Poland }\end{array}$ & $\begin{array}{l}\text { Tertiäärinen, pun. savi } \\
\text { Red clay of Tertiär age }\end{array}$ & & & $<100$ \\
\hline $\begin{array}{l}\text { Puola, Kobierniki } \\
\quad-\text { Poland }\end{array}$ & $\begin{array}{l}\mathrm{HHt}-\text { lössi } \\
\text { Finer finesand - loess }\end{array}$ & 17 & 20 & $30-50$ \\
\hline $\begin{array}{l}\text { Saksa, Pfalzdorf } \\
\text { - Germany }\end{array}$ & $\begin{array}{l}\mathrm{KHt} 50 \mathrm{~cm} / \mathrm{hs} \mathrm{KHt} \\
\text { Coarser finesand/silty loam }\end{array}$ & 10 & 37 & $20-40$ \\
\hline $\begin{array}{l}\text { Tanska, Aarösund } \\
\text { - Danmark }\end{array}$ & $\begin{array}{l}\mathrm{HtMr} 30 \mathrm{~cm} / \mathrm{hk} \mathrm{Lt} \\
\text { Moraine } 30 \mathrm{~cm} / \text { sandy loam }\end{array}$ & 16 & 22 & $20-40$ \\
\hline- & $\begin{array}{l}\text { Lt } \\
- \text { Loam }\end{array}$ & 40 & 11 & $10-50$ \\
\hline $\begin{array}{l}\text { Tanska, Blanksted- } \\
\text { gaard } \\
\quad \text { - Danmark }\end{array}$ & $\begin{array}{l}\text { hk SMr, kalkkimergeliä }(50-\mathrm{cm}) \\
\text { Moraine }+ \text { limemergel }(50-\mathrm{cm})\end{array}$ & 27 & 38 & $20-60$ \\
\hline
\end{tabular}

destä (taul. 2). Erityisesti on huomattava, että vanhoissakin (yli 20 ja $30 \mathrm{v}$ ) puissa juuristo on pääosaltaan melko matala $(<60 \mathrm{~cm})$.

\section{Yhteenveto}

Tutkimus suoritettiin sektorilla $\left(30-180^{\circ}\right)$, jonka maa poistettiin kerroksittain $(5,10$ ja $20 \mathrm{~cm})$ ja vyöhykkeittäin $(30$ tai $50 \mathrm{~cm})$. Tästä maasta erotettiin juuret, jotka punnittiin kahtena eränä (paksut $>2 \mathrm{~mm}$ ja hienot $<2 \mathrm{~mm}$ ). Muita tutkimuksia varten otettiin myös vastaavat maanäytteet, joista tehtyihin tutkimuksiin ei tässä yhteydessä kajota. Yhteenvetona tutkituista tapauksista voidaan tehdä seuraavia päätelmiä.

Juuristo leviää nuorilla puilla suhteellisesti nopeammin kuin latvus ja saattaa ulottua 1-1.5 metriä latvuksen kehän ulkopuolelle.

Omenapuun juuristo muodostuu yleensä tasapaksuun kerrokseen, joka nuorilla puilla on $40-50 \mathrm{~cm}$ paksu ja syvenee iän mukana. Parhaissa maissa $(\mathrm{HHt})$ se ulottuu vanhemmissa puissa (n:ot 6 ja 7 ) metrin syvyyteen. Tiiviisiin maihin juuristo ei mene niin syvälle (esim. AS n:o 9). Hiekassa juuristo keskittyy multakerroksen alaosaan ja välttää selvästi auhtoa pohjamaan hiekkaa (n:ot 4 ja 5).

Mulloksella pidetyssä maassa juuristo karttaa muokattavaa kerrosta, joka eri olosuhteissa on 5-20 $\mathrm{cm}$ paksu (esim. n:ot 6 ja 7 ). 
Nurmi ja kate maan pinnalla näyttävät olevan juurille erittäin edullisia koska juuristo niiden alla nousee aivan maan pintaan saakka.

Pääasiallinen juuristokerros omenapuilla alkaa noin $10 \mathrm{~cm}: n$ syvyydestä ja ulottuu noin $50 \mathrm{~cm}$ :iin. Tässä kerroksessa yleensä on suurin juuritiheys.

Useimmissa tapauksissa juuritiheys on melko tasainen $(0-50 \mathrm{~cm}: n$ kerroksessa) aivan rungon lähiympyrää $(0-90 \mathrm{~cm})$ lukuunottamatta.

Juuriston levinneisyyttä selvittelevä tutkimus on osa laajemmasta hedelmätarhojen maaprofiilia koskevasta tutkimuksesta, jonka tarkoituksena on hedelmätarhan viljavuuskysymysten käsittely. Tässä työssä muodostaa puiden juuriston selvittely hyvin oleellisen osan. Omenapuun osalta voidaan tutkimuksen tuloksia jo käyttää hyväksi esim. viljelyteknillisiä ratkaisuja suunniteltaessa. Erityisesti maan pinnan hoito ja hedelmätarhan lannoitus ovat kysymyksiä, joissa nimenomaan juuristo on tärkeimpiä tekijöitä. Myös tarhan sijoittamisessa, jolloin maalaji on otettava huomioon, on tämän tutkimuksen tuloksilla merkityksensä.

\section{KIRJALLISUUTTA}

(1) Albrecht, D. 1955. Verbessertes Verfahren der Freilegung der Wurzelkrone unter Beibehaltung ihrer natürlichen Lage. Archiv f. Gartenbau 3: 11-16.

(2) Сhalyt, M. S. 1950. Der unterirdische Teil einiger Wiesen-, Steppen- und Wüstenpflanzen und die Phytozinose. Geobot. Moskau (Ref. Kullmann, 1957).

(3) Goff, E. S. 1897. A Study of the roots of certain perennial plants. Wisconsin Agric. Exp. Sta. Rep. 14: $286-298$.

(4) GorsskopF, W. 1950. Bestimmungen der charakteristischen Feinwurzelintensitäten in ungünstigen Waldbodenprofilen und ihre ökologische Auswertung. Mitt. d. Bundesanst. f. Forst und Holzwirtschaft. (Ref. Kullmann, 1957.)

(5) Hellrigel, H., 1883. Beiträge zu den naturwissenschaflichen Grundlagen des Ackerbaues. Braunschweig.

(6) Krassilnikow, P. K. 1950. Zur Frage über die Methodik des Studiums der Wurzelsysteme der Holzarten bei den Expeditionsgeobotanischen Forschungen. Bot. J. d. Akademie d. Wiss. d. UdSSR. 35. Moskau. (Ref. Kullmann, 1957.)

(7) Kullmann, A. 1957. Zur Intensität der Bodendurchwurzelung. Z. f. Acker- und Pflanzenbau 103: 189-197.

(8) Könekamp, A. H. 1953. Teilergebnisse von Wurzeluntersuchungen. Z. f. Pflanzenern., Düng. u. Bodenk. 60: 113-124.

(9) Laitakari, E. 1927. Männyn juuristo. Helsinki.

(10) Lehtonen, V. 1946. Omenaviljely. Helsinki. 1-279.

(11) Liebig, J. von 1862. Die Chemie in ihrer Anwendung auf Agrikultur und Physiologie. 2. Teil: Naturgesetze des Feldbaues. Braunschweig.

(12) Pogrebnjak, P. S. 1927. Das Wurzelsystem in dem Waldhorizonten. (Ref. Kullmann, 1957.)

(13) SAlonen, M. 1949. Tutkimuksia viljelyskasvien juurten sijainnista Suomen maalajeissa. Acta agr. fenn. 70, 1: 1-91.

(14) Weaver, J. E. 1926. Root development of field crops. New York. I-XII, 1-291.

(15)VUorinen, J. E. 1955. Havaintoja perusrunkojen kestävyydestä. Hedelmälehti 2: 47-49.

(16) YLI-VAKKURI, P. 1954. Tutkimuksia puiden välisistä elimellisistä juuriyhteyksistä männiköissä. (Referat: Untersuchungen über organische Wurzelverbindungen zwischen Bäumen in Kieferbestäden.) Acta forest. fenn. 60, 3: 1-102. 


\title{
S U M M A R Y :
}

\section{ON THE ROOT SYSTEM OF APPLE-TREES}

\author{
JOUKO VUORINEN
}

\section{Agricultural Research Centre, Department of Soil Science, Helsinki}

This study of the root systems of apple-trees was carried out on four Finnish soil types in the years 1955-57. Trees of several ages were investigated in Pikkola orchard at Kangasala, where there was sand soil (Figures 1-5) and silt soil (Fig. 8). The same investigations concerning fine sand soil were made at Häme Agricultural Experiment Station at Pälkäne (Figures 6 and 7), concerning heavy clay (Fig. 9) in Koivula orchard at Hirvensalo, and concerning other soil conditions in the orchard of the Institute of Pomology at Skierniewice in Poland (Fig. 10).

Field work was carried aut on a sector of $30-180^{\circ}$ in 5,10 and $20 \mathrm{~cm}$. layers and in 30 or $50 \mathrm{~cm}$. belts. The soil was taken out on a sieve and the roots cleaned by hand without water. The roots were classifield into two groups, above and below $2 \mathrm{~mm}$. For other determinations soil samples were taken.

This investigation concerning the spreading of the root system is a part of a more extensive study of soil profile in orchards to elucidate some problems about orchard soil fertility. In this connection a knowledge of the root systems of the trees is a very important question. Regarding apple-trees, the results of this investigation can be used in planning steps for better management of the orchard soil. Especially mulching, manuring and fertilizing have a very close connection with the root system. In establishing new orchards it is important to know the relation between the roots and the soil. With regard to these considerations some conclusions have been made:

\section{Conclusions}

The root system spreads relatively more rapidly than the crown of the tree in young trees and it can reach $1-1.5$ meters outside the crown circle.

The root system of the apple-tree usually distributes itself to an equal depth in the soil, which in young trees consists of $40-50 \mathrm{~cm}$., and which goes deeper with age. Under the best conditions (in finer finesand) the root system of older trees reaches a depth of one meter (Figures 6 and 7). In compact soils the root system does not go so deep (e.g., in heavy clay, Fig. 9). In sand soil the root system concentrates itself in the lower layer of the mould horizon and clearly avoids the dry sand in the subsoil (Figures 4 and 5).

In clean cultivated orchards the root system avoids the tilled layer. The thickness of this rootless horizon varies between $5-20 \mathrm{~cm}$.

Sod and mulch seem to provide good conditions for the roots; thus the root system below these rises to the soil surface.

The mean layer of the root systems of apple-trees begins at a depth of $10 \mathrm{~cm}$ and reaches to $50 \mathrm{~cm}$. The root density in this layer is usually the greatest.

In most cases the root density is almost equally distributed over the layer $0-50 \mathrm{~cm}$., except for the inner circle of radius $0-90 \mathrm{~cm}$. 